\title{
Effects of Service Quality and Customer Satisfaction on Customers' Loyalty in the Hospitality industry of Ghana
}

\author{
Ibrahim Ofosu-Boateng and Philip Acquaye
}

\begin{abstract}
The purpose of the study was to investigate the effects of service quality and customer satisfaction on customers' loyalty in the hospitality industry in Cape Coast, Ghana. Descriptive design was used to investigate the association between service quality, customer satisfaction, service quality and customer satisfaction (independent variables) and customers' loyalty (dependent variable). Survey was used for data collection from 320 customers in the hospitality industry in Cape Coast, Ghana. Data analysis was carried out with the use of SPSS version 20. The findings showed a significant positive relationship between service quality and customers' loyalty in the hospitality industry in Cape Coast, Ghana. The study also found a significant positive relationship between customer satisfaction and customers' loyalty in the hospitality industry in Cape Coast, Ghana. It was recommended that the firms in the hospitality industry in Cape Coast, Ghana, should strive to continue the delivery of quality service to ensure loyalty. This can be done by maintaining consistent quality service performance. Also, it was recommended that the firms in the hospitality industry in Cape Coast, Ghana, should continue to endeavour to meet customers' expectation since it engenders loyalty. Periodic market research is imperative to help identify emerging needs of customers so as to enhance the loyalty.
\end{abstract}

Index Terms - service quality, customer satisfaction, customer loyalty, hospitality industry, Cape Coast, Ghana.

\section{INTRODUCTION}

\section{A. Background of the Study}

The heightened competition coupled with the persistent evolution in today's business environment has given service providers the cause to focus on offering quality service in order to satisfy customers, and to induce loyalty. Wilson \& Campbell [1] and Ryall \& Kruithof [2] have defined quality as "meeting customer expectations". Zeithaml et al. [3] defined service as "deeds, performances and processes provided or co-produced by one entity or person for and with another entity or person". According to Hoffman \& Bateson [4], service quality is the customer's perception of the general service performance of a company in a longterm setting. Also, Seth et al. [5] view service quality as "the ability to match expected service with perceived service to achieve customer satisfaction". Given the rise in the service economy, the success of service providers, to a large extent, depends on their ability to provide customer-centered services [6]. Thus, service quality has become significant for

Published on October 25, 2020.

Dr. Ibrahim Ofosu-Boateng, West End University College, Ghana.

(corresponding e-mail: ibraboat48@yahoo.com)

Philip Acquaye, BlueCrest University College, Ghana.

(e-mail: philacq@gmail.com) the survival and sustainability of organizations in the face of vehement competition [7]. In support of Khan \& Fash [7], Sureshchandar et al. [8] posits that good service quality does not only result in customer satisfaction but can also aid organizations to gain a successful competitive edge over competitors. Hansemark \& Albinsson [9] and Kotler [10] defined satisfaction "as an overall customer attitude or behaviour towards a service provider, or an emotional reaction towards the difference between what customers expect and what they receive, regarding the fulfillment of some desires, needs or goals.

Liu \& Khalifa [11] link service quality to organizations' profitability, costs, repeat purchase and customer satisfaction. Brophy et al. [12] intimated that since consumers' needs/wants and expectations regarding their purchasing experiences keep evolving, service quality and customer satisfaction must be considered indispensable in the service economy [13]. Customer satisfaction has been defined as 'the result of customers' comparison of perceived quality and actual service performance" [14]. Johanson \& Ström [15] explained customer satisfaction as "a state of mind that a customer has about a company when their expectations have been met or exceeded over the lifetime of the product or service. In enumerating the benefits of customer satisfaction, Zeithaml et al. [3] posited that customer satisfaction information can help organizations to evaluate their ability in meeting customers' needs and expectations effectively. Zairi [16] is also of the view that attaining customer satisfaction induces repurchase and customer loyalty. Hussain et al. [17] equally explained in their study that loyal consumers tend to spread a positive word-of-mouth, as well as frequently buy new products that the organization produces, which are both positive consequences for the organization.

In the light of the aforementioned, the firms in the hospitality industry in Ghana have sought to offer service quality and customer satisfaction services to customers to effectuate loyalty since, according to Goodman [18], dissatisfied customers might tell, on average, ten people about the organization as against 5 people by satisfied customers. Again, Goodman [18] maintained that it costs five times to attract a new customer than to maintain a current customer.

This study therefore seeks to examine the effects of service quality and customer satisfaction on customer loyalty in the hospitality industry of Ghana.

\section{B. Statement of the Problem}

The hospitality industry in Ghana is a thriving one as Ghana is endowed with rich cultures and fascinating tourist attraction sites. Nonetheless, the industry faces fierce 
competition, so offering service quality and customer satisfaction has been emphasized as a strategic marketing tool by the hospitality firms to induce customer loyalty. Studies conducted by Newman [19] and Caruana [20] found service quality and customer satisfaction to be related to customer loyalty through repurchase intentions. The study of Saleem \& Raja [21] has also revealed a positive relationship between service quality, customer satisfaction, loyalty and brand image. Equally, Prabhakaran \& Satya [22] found a link between service quality and customers' satisfaction which helps to induce loyalty. Interestingly, that there is a general perception, that both service quality and customer satisfaction influence customers' loyalty is as a result of heterogeneous factors that differ largely from one geographical area to the other [23]. To the best knowledge of researchers, these studies had been carried out in geographical locations entirely different from those in Ghana. Quite significantly, few studies conducted on the hospitality industry in Ghana had focused on trust and commitment [24], relationship marketing and service quality [25], service quality and loyalty [26]. Apparently, there seems to suggest a paucity of study on the effects of service quality and customer satisfaction on customer loyalty in the hospitality industry in Cape Coast, Ghana. This study seeks to fill this gap in knowledge by examining the effect of service quality and customer satisfaction on customer loyalty in Cape Coast, Ghana, thus contributing to the existing academic literature on the subject.

\section{Statement of Hypotheses}

The following null hypotheses have been formulated to guide the researchers in the pursuit of the study.

i. service quality will not have a positive relationship with customers' loyalty in the hospitality industry in Cape Coast, Ghana; ii. customer satisfaction will not have a significant positive relationship with customers' loyalty in the hospitality industry in Cape Coast, Ghana and;

iii. Service quality and customer satisfaction will not have a significant positive relationship with customers' loyalty in the hospitality industry in Cape Coast, Ghana.

\section{LITERATURE REVIEW}

\section{A. Service Quality}

According to Wisniewski [27], service quality has aroused considerable interest and debate in the research literature because of the lack of general consensus regarding not only its definition but measurement as well. It is interesting to note the existence of several definitions on the subject. For instance, Parasuraman et al. [28] defined service quality as "the overall evaluation of a specific service firm that results from comparing that firm's performance with the customer's general expectations of how firms in that industry should perform. Nitecki \& Hernon [29] defined service quality in terms of "meeting or exceeding customer expectations, or as the difference between customer perceptions and expectations of service." Lewis \& Mitchell [30] defined service quality as the extent to which a service meets customers' needs or expectations. Arnauld et al. [31] also defined it as "an attitude formed by a long-term and overall evaluation of a performance". Service quality has been conceptualized as a function of consumer expectations towards the service situation and process. Parasuraman et al. [32] developed a conceptual model of service quality where the authors identified five gaps that could impact consumers' evaluation of service quality. These five gaps are presented in Fig. 1.

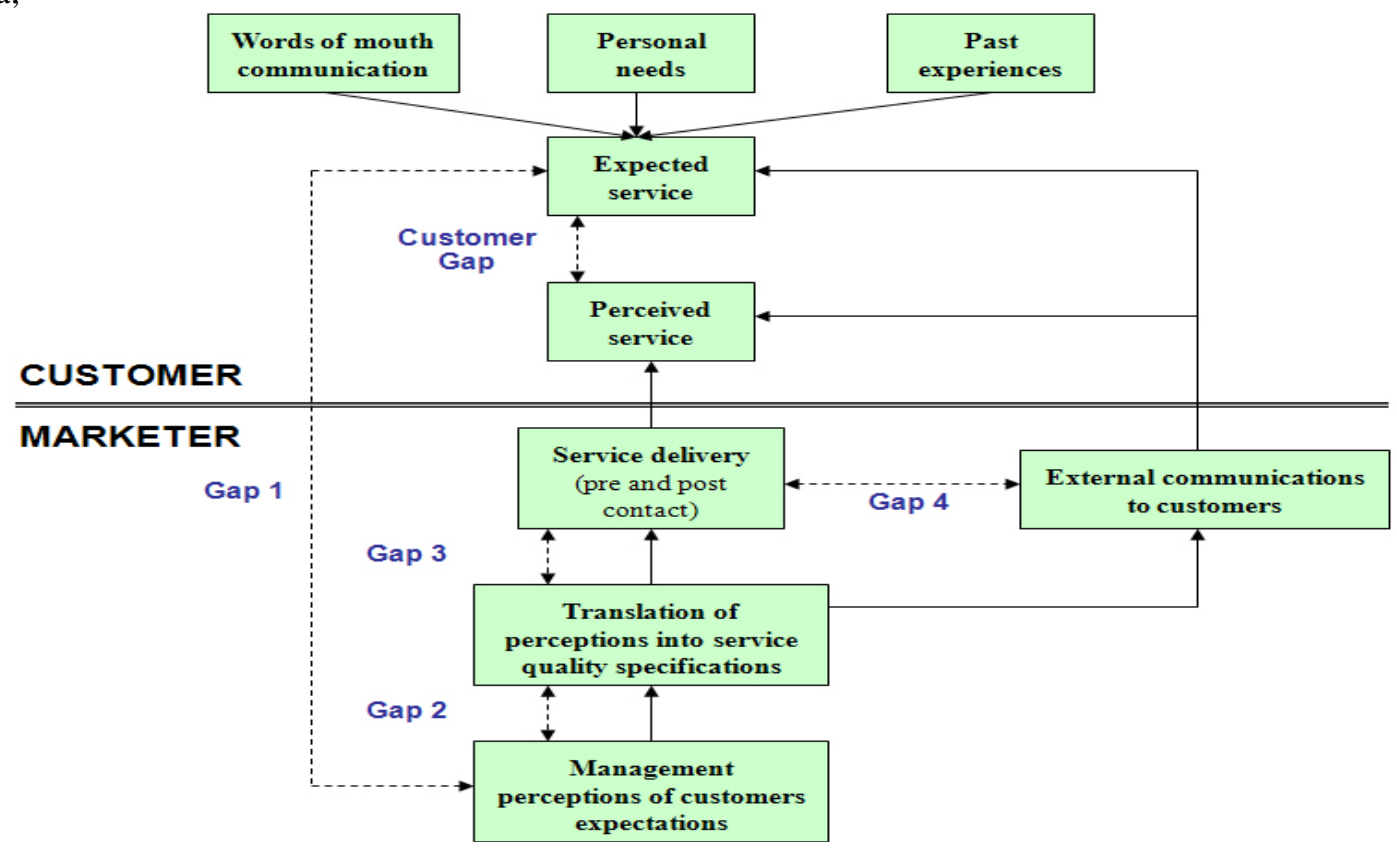

Fig. 1. Service Quality Model [32].

Gap 1: Customers expectation--customer perceptions: This refers to the gap difference between customers' expectations and customers' perceptions. Customers' expectations are what customers expects according to available resources which are influenced by cultural background, family lifestyle, personality, demographics, advertising, experience with similar products, information available online etc.

Gap 2: The knowledge gap: This gap is the difference between customers' expectations and management's perception. In most cases managers are not aware or have 
not correctly interpreted customers' expectation in relation to organization's services or products.

Gap 3: The Policy Gap: This gap occurs as a result of the variance between management's perception and service quality specification. Such a gap reflects management's incorrect translation of the service policy into rules and guidelines for employees.

Gap 4: The Delivery Gap: This gap refers to the difference between service quality specification and service delivery. Organizations with a delivery gap may specify the service required to support consumers but have subsequently failed to train their employees and also not formulating good processes and guidelines for implementation.

Gap 5: The Communication Gap: This gap is the variance between service delivery and external communications. In some cases, the gap occurs when the promises made by organizations through promotions do not match the actual service delivery.

The authors also defined 10 service gap dimensions such as: tangibility, reliability, responsiveness, competence, courtesy, credibility, security, communication, understanding and knowing the customers. However, in 1988, these ten dimensions were broken down into five. These five dimensions are presented in Table 1.

TABLE I: SERVICE QUALITY DIMENSIONS [28]

\begin{tabular}{|l|l|}
\hline Tangibles & $\begin{array}{l}\text { These include the appearance of employees, } \\
\text { physical facilities being offered and equipment } \\
\text { which form part of service experience }\end{array}$ \\
\hline Reliability & $\begin{array}{l}\text { The way the service is being delivered, that is, the } \\
\text { ability to deliver the promised service precisely and } \\
\text { consistently. }\end{array}$ \\
\hline Responsiveness & $\begin{array}{l}\text { Willingness to help customers, respond to their } \\
\text { queries and also to provide rapid service to them. }\end{array}$ \\
\hline Assurance & $\begin{array}{l}\text { Understanding and courtesy of staffs and their } \\
\text { capability to inspire trust and confidence. }\end{array}$ \\
\hline Empathy & $\begin{array}{l}\text { Helpful, care about the customers' requirements } \\
\text { and the firm provides individualized attention to its } \\
\text { customers with compassion. }\end{array}$ \\
\hline
\end{tabular}

\section{B. The Concept of Customer Satisfaction}

According to Hill et al. [33]. the concept of customer satisfaction has been in existence for a very long time probably spanning over 200 years and its relevance has continued to receive immense attention especially in the 21st century. Ofosu-Boateng \& Samuel Dwamena [34] attributed this to the turbulent nature of the business environment which has made it near impossible for organizations to survive without placing the customer at the center of their operations. Kaura et al. [35] defined customer satisfaction as "the physiological state of emotion associated with the conformity or nonconformity of a consumer's perceived quality of service during and after service experience". Homburg \& Giering [36] posit that a satisfied customer often purchases more products/services on a regular basis which can influence loyalty in the long run.

\section{Components and Requirements of Customer Satisfaction}

According to McColl-Kennedy \& Schneider [37], the concept of customer satisfaction is composed of several components from distinct sources. McColl-Kennedy \& Schneider [37] posited that customer satisfaction starts with clear and operational definitions from both the customer and the organization and that, understanding the motivations, expectations, and desires of both gives a foundation to how best it is to assist the customer. This can as a matter of fact provide information on making improvements in the nature of service delivery. Naylor \& Greco [38] call this as "the heart of research into customer satisfaction". The importance of clearly defining the key concepts and elements of satisfaction provide a template by which information can be assembled about what is, and what is not working.

\section{Customer Loyalty}

Customer loyalty has become a significant choice for organizations to survive the strenuous competition in the business environment. It is about how organizations create and retain a relationship with their customers to enhance repeat purchases. Kim et al. [39] defined customer loyalty as "a combination of customers' favourable attitude and the behaviour or repurchases". Customer loyalty refers to a psychological tendency of customers to trust in the product/service and brand of organizations and the repeat purchase after customer satisfaction. Gerpott et al. [40] also defined it as "customers' repeated behaviour to transact business with an organization or purchase the same brand repeatedly" and according to Bansal \& Gupta [41], customer loyalty has become indispensable for sustainable competitive advantage. Generally, it is believed that loyal customers rarely respond to overtures from competitors. At the very least, loyal customers will help consolidate existing market, reduce marketing costs, enhance the core competitiveness and improve the long-term business performance.

\section{E. Relationship between Service Quality and Customer Loyalty}

Service quality has been conceptualized as a function of consumer expectations and performance. It measures how well the service level delivered meets customers' expectations on a consistent basis. Service quality is considered very important because it can lead to higher customer satisfaction, profitability, cost reduction, customer loyalty and retention. This assertion is supported by Zeithaml [3] who explained that service quality creates an essential ingredient for establishing and maintaining loyal and profitable customer base. Also, the study of Kumar et al. [42] revealed that a high quality of service will result in a high customer loyalty. Wong \& Sohal [43] in their study found out that service quality has strong and significant relationship with customer loyalty. However, in the study of Aydin \& Ozer [44], the researchers found out that service quality is necessary but insufficient to induce customer loyalty. Additionally, the study of Wong \& Sohal [45] revealed a positive association between service quality and customer loyalty.

\section{F. Relationship between Customer Satisfaction and Customer Loyalty}

Customer satisfaction is the result of consumers' expression of contentment with the general experience of a purchase, which includes the service quality among other aspects of the purchasing experience. Ciavolino \& Dahlgaard [46] defined customer satisfaction as "the overall evaluation of the service performances or utilization". Namkung [47] views it as "the customers' overall evaluation 
of their purchase experience of a product or service. Customer satisfaction has been recognized as an important factor to influence customer referrals and customer loyalty. In buttressing this, Shafei \& Tabaa [48] is of the view that customer satisfaction does not only influence customer referrals and repeat purchases but also impact positively on financial position of organizations. A study conducted by Ofosu-Boateng \& Dwamena Agyei [34] found a strong positive relationship between customer satisfaction and customer loyalty in the Ghanaian banking industry. However, the study of Kwak et al. [49] revealed that customer satisfaction does not have a direct inducement on customer loyalty. Also, the study of Bowen \& Chen [50] argued that the customer satisfaction and loyalty relationship becomes significant only when customers become extremely satisfied.

\section{G. Relationship between Service Quality, Customer Satisfaction and Customer Loyalty}

The importance of service quality, customer satisfaction and customer loyalty are replete need for organizations to understand them have become imperative for sustainable competitive advantage due to the surging competition in the business environment. In support of this, Chingang Nde et al. [51] intimated that service quality and customer satisfaction has become important concepts which organization need to understand in order to remain competitive in business. Service quality is thus seen as an essential sign of customer satisfaction which in turn induces customer loyalty. According to Mcdogall \& Levesque [52] and Negi [53], service quality leads to satisfaction which is a potential tool to influence customer loyalty in the long run. A study conducted by Mahamad \& Ramayah [54] showed a positive and meaningful relationship among all the service quality dimensions with satisfaction and loyalty. Also, the findings of Gray \& Boshoff [55] revealed that the service quality dimensions empathy and assurance impact positively on both customer loyalty and customer satisfaction.

\section{H. Empirical Review}

Hennayake [13] conducted a study on the impact of service quality on customer satisfaction of public sector commercial banks in Sri Lanka. The study found a significant relationship between service quality and customer satisfaction. Also, Naderian \& Baharun [56] found positive relationship between service quality and loyalty in the hospitality industry in Malaysia. Ofosu-Boateng \& Dwamena Agyei [34] carried out a study on effects of customer satisfaction and marketing communication mix on customers' loyalty in the Ghanaian banking industry. The study revealed a strong positive relationship between customer satisfaction and customer loyalty. The study of Pereira et al. [57] revealed a positive and significant effect towards customer satisfaction and loyalty. Baker \& Crompton [58] reported a positive relation between service quality and willingness to pay higher prices and to customer loyalty.

\section{Methodology}

\section{A. Research Design}

Research design can be thought of as the structure of the research. It is the glue that holds all the elements of the study. This study is descriptive and cross-sectional in nature. Descriptive design allows a researcher to conduct interviews or administer questionnaire to a sample of individuals or respondents. Also, cross-sectional surveys make it possible for a group of respondents to be asked a set of questions at one point in time [59]. In this study, questionnaire was administered to respondents at a given point in time making the chosen research design appropriate for the study.

\section{B. Population of the Study}

According to Opoku [60], a research population is generally a large collection of individuals or objects that is the main focus of a scientific query. Castilo [61] defines it as "the universal set of all the existing people, units, items or events that contain characteristics of interest as well as all the set of possible data values for a subject under study". The population of the study comprises all customers of the hospitality industry in Cape Coast, Ghana.

\section{Sampling Technique and Sample Size}

\section{Sampling Technique}

According to Panneerselvam [62], sampling technique is the means of ascertaining or selecting a unit from a group of population of a study by way of assembling data collection about their individual characteristics. There are two broad types of sampling thus, probability and non-probability sampling. In this study, the non-probability sampling particularly convenience sampling technique was used.

\section{Sample Size}

Since it was impractical to administer questionnaire to all the customers of the hospitality industry in Cape Coast, Ghana, a sample was drawn to make inferences about the entire population [63]. In this regard, a sample size of 320 was selected to represent the entire population of the study.

\section{Data Collection Instrument}

The study used field survey to solicit data. Questionnaire was the main instruments for data collection. According to Panneerselvam [62], a questionnaire involves a set of wellformulated questions which helped to probe and obtained response from the respondents. Therefore, questionnaire was administered to solicit responses to achieve the objective of the study.

\section{E. Distribution of the Questionnaire}

The administering of questionnaire had taken longer than usual due to the COVID-19 outbreak. Approximately 60 days was used to administer the questionnaire and conduct interviews. Each respondent spent about 30 minutes on average in answering the questionnaire.

\section{F. Data Analysis}

The main instrument for data analysis was Statistical Package for the Social Sciences (SPSS) version 20. A Cronbach's alpha $(\alpha)$ coefficient analysis was used to ascertain the internal consistency of the responses solicited. The Pearson's correlation was employed to investigate the strength of relationship between the independent variables 
(service quality, customer satisfaction, service quality and customer satisfaction) and the dependent variable (customer loyalty). Also, the linear regression was run to determine how the increase/decrease of the independent variable affects the dependent variable percentage wise. For easy reading, the findings are presented in tables with accompanied succinct commentary.

\section{G. Validity and Reliability}

Saunder et al. [64] defined validity as "the extent to which data collection methods accurately measures what they were intended to measure". To ensure validity, the questionnaire was pre-tested using respondents with similar characteristics of the study. Panneerselvam, [62] defines pre-testing of questionnaires as a "means of obtaining information to improve its content, format and sequence. Reliability on the other hand examines the extent to which a scale produces consistent results if repeated measurements are made. Morse et al. [65] referred to it as "a precondition for validity". To ascertain the internal consistency of the results received from respondents, the Cronbach's alpha coefficient analysis was employed.

\section{H. Ethical Consideration}

The main ethical concerns regarding this study were consent and anonymity. Kök \& Fisher [66] regarded informed consent as a key issue in research ethics. Therefore full consent of participants was sought before the commencement of the study. Also, anonymity of participants was ensured

\section{Proposed Conceptual Framework}

In order to test the stated hypotheses i.e. the relationship between service quality, customer satisfaction, service quality and customer satisfaction (independent variables) and customer loyalty (dependent variable), the study developed a construct as shown in Fig. 2.

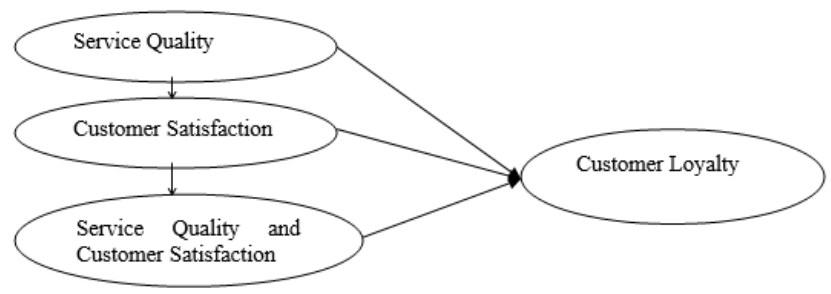

Fig. 2. Conceptual Framework.

\section{J. Overview of the Hospitality Industry in Ghana}

Ghana's hospitality industry is 4th in ranking for profitability in African. Ghana is located on the West Coast of Africa near Cote D'Ivoire and Togo. One of the main reasons for the growth in the hospitality business is the stable government and economy, which infers more safety, and the growing middle class in Ghana. Due to the tourism and the ability for growth, large hotel chains like Marriott, Radisson and other chains have opened their hotels in Ghana. The industry continues to grow at an exponential rate. The Kakum National Park, Labadi Beach, Elmina Castle, the mighty Volta Lake, and the Akosombo Dam are just a few of the sites attracting foreign traffic to the country

\section{REsults AND Discussion}

\section{A. Background Characteristics of Respondents}

The demographic analysis of gender was sought. Out of the 320 population, $150(46.9 \%)$ were male whilst 170 $(53.1 \%)$ were female. The statistics demonstrates that female customers dominate the male customers in the hospitality industry in Cape Coast, Ghana.

The results of the study showed the dominance of age groups $40-49(37.5 \%)$ and $50-59(31.2 \%)$ in the hospitality industry in Cape Coast, Ghana. This is followed by age group 30-39 (21.3\%) and age group 20-29 (10\%) respectively.

The findings showed that customers with other certificates other than professional, bachelor and master's degree were the majority $140(43.8 \%)$ followed by master degree holders, bachelor degree holders and professional certificate holders. Representing 80 (25.0), 66 (20.6\%), 34 (10.6) respectively in the hospitality industry in Cape Coast, Ghana. The results are presented in Table 2.

TABLE 2: DEMOGRAPHIC ANALYSIS OF RESPONDENTS

\begin{tabular}{lcc}
\hline Characteristics & Frequency & Percent (\%) \\
\hline Gender $(\mathbf{N}=\mathbf{3 2 0})$ & 150 & \\
Male & 170 & 46.9 \\
Female & & 53.1 \\
Age in years $(\mathbf{N = 3 2 0})$ & 32 & \\
$20-29$ & 68 & 10.0 \\
$30-39$ & 120 & 21.3 \\
$40-49$ & 100 & 37.5 \\
$50-59$ & & 31.2 \\
Educational Background $(\mathbf{N = 3 2 0})$ & 34 & \\
Professional cert. & 66 & 10.6 \\
Bachelor's degree & 80 & 20.6 \\
Master's degree & 140 & 25.0 \\
Other cert. & & 43.8 \\
\hline
\end{tabular}

\section{B. Reliability Statistics}

The reliability of a measure shows the degree to which the measure is without bias (error free) and hence offers consistent measurement across time and across different items in the instrument [67]. According to Sekaran [67], a measure with reliability less than 0.6 is considered poor, it should be at least 0.70 or above. In this study, the Cronbach's Alpha $(\alpha)$ test carried out on the responses received recorded a higher internal consistency (0.886) which is higher and above 0.70 and therefore considered valid. The result is presented in Table 3.

TABLE 3: RELIABILITY STATISTICS.

\begin{tabular}{cc}
\hline Cronbach's Alpha (a) & Number of Items \\
SOURCE: RESEARCHER's FIELD WORK, AUGUST, 2020
\end{tabular}

\section{Pearson's Correlation Analysis}

The correlation analysis shows the relationship between the independent variable (service quality) and the dependent variable (customer loyalty). The correlation between the two variables shows $r=0.523$ and $p=0.0001$. The strength of the relationship can be said to be positive in that a unit increase in service quality will result in 0.523 increases of customer 
loyalty. Table 4 presents the results.

TABLE 4: PEARSON's CORRELATION BETWEEN SERVICE QUALITY AND CUSTOMER LOYALTY

\begin{tabular}{cccc}
\hline & & CL & SQ \\
\hline Customer Loyalty & Pearson Correlation & 1 & $.523^{* *}$ \\
& Sig. (2 tailed) & & .0001 \\
& $\mathrm{~N}$ & 320 & 320 \\
Service Quality & Pearson Correlation & $.523^{* *}$ & 1 \\
& Sig. (2 tailed) & .0001 & \\
& $\mathrm{~N}$ & 320 & 320 \\
\hline
\end{tabular}

**. Correlation is significant at the 0.01 level (2-tailed).

*** CL denotes Customer loyalty whist SQ denotes Service quality. Source: Researcher's Field Work, August, 2020.

The statistics shows the strength of the relationship between the independent variable (customer satisfaction) and the dependent variable (customer loyalty). The strength between the two variables is shown to be positive $r=0.523$ and $\mathrm{p}=0.0001$. The findings imply that a unit increase in customer satisfaction will result in .426 increases in customer loyalty. Table 5 presents the results.

TABLE 5: PEARSON'S CORRELATION BETWEEN CUSTOMER SATISFACTION

\begin{tabular}{cccc}
\multicolumn{4}{c}{ AND CUSTOMER LOYALTY } \\
\hline & & CL & CS \\
\hline Customer Loyalty & Pearson Correlation & 1 & $.426^{* *}$ \\
& Sig. (2 tailed) & & .0001 \\
& N & 320 & 320 \\
Customer Satisfaction & Pearson Correlation & $.426^{* *}$ & 1 \\
& Sig. (2 tailed) & .0001 & \\
& N & 320 & 320
\end{tabular}

**. Correlation is significant at the 0.01 level (2-tailed).

*** CL denotes Customer Loyalty whist CS denotes Customer Satisfaction.

Source: Researcher's Field Work, August, 2020.

The findings show the strength of the relationship between the independent variables (service quality, customer satisfaction and the dependent variable (customer loyalty). The results demonstrate a positive relationship between the variable as shown $r=0.684$ and $p=0.0001$. This implies that a unit increase in both service quality and customer satisfaction will result in .684 increases in customer loyalty. Table 6 presents the results.

TABle 6: Showing Pearson's CorRelation Between SERVICE QUALITY, CUSTOMER SATISFACTION AND CUSTOMER LOYALTY

\begin{tabular}{cccc}
\hline & & CL & SQ and \\
& & CS \\
\hline Customer Loyalty & Pearson Correlation & 1 & $.684^{* *}$ \\
& Sig. (2 tailed) & & .0001 \\
& N & 320 & 320 \\
Customer & Pearson Correlation & $.68 .4^{* *}$ & 1 \\
Satisfaction & Service Quality and Sig. & .0001 & \\
& $(2$ tailed) & 320 & 320
\end{tabular}

**. Correlation is significant at the 0.01 level (2-tailed).

*** CL denotes Customer Loyalty and SQ and CS denote Service Quality and Customer Satisfaction.

Source: Researcher's Field Work, July, 2019.

\section{Linear Regression Analysis}

\section{Model Summary}

The entire summary of findings with the use of regression analysis was determined where $\mathrm{R}$ square shows the variation in the independent variables (service quality, customer satisfaction and service quality and customer satisfaction) and the dependent variable (customer loyalty). The R square value of .622 implies $62.2 \%$ influences of the independent variables (service quality, customer satisfaction and service quality and customer satisfaction) on the dependent variable (customer loyalty). The result is presented in Table 7.

TABLE 7: MODEL SUMMARY

\begin{tabular}{|c|c|c|c|c|}
\hline Model & $\mathbf{R}$ & R Square & $\begin{array}{l}\text { Adjusted R } \\
\text { Square }\end{array}$ & $\begin{array}{c}\text { Std. Error } \\
\text { of the } \\
\text { Estimate }\end{array}$ \\
\hline 1 & $.568^{\mathrm{a}}$ & .622 & .484 & .74294 \\
\hline
\end{tabular}

\section{ANOVA}

The acceptance or otherwise of the level of significance was determined by the use ANOVA. The findings demonstrate a significant level of $0.000 \mathrm{a}$ which obviously is less than .05 indicating acceptance and demonstrates a strong inducement of service quality, customer satisfaction and service quality and customer satisfaction on customer loyalty. Table 8 presents results.

\begin{tabular}{lccccc}
\multicolumn{6}{c}{ TABLE 8: ANOVA } \\
\hline Model & $\begin{array}{c}\text { Sum of } \\
\text { Squares }\end{array}$ & df & $\begin{array}{c}\text { Mean } \\
\text { Square }\end{array}$ & F & Sig. \\
\hline Regression & 62.426 & 2 & 18.892 & 44.270 & $.000 \mathrm{a}$ \\
Residual & 14.772 & 824 & .684 & & \\
Total & 77.198 & 826 & & & \\
\hline a. Predictors: (Constant), service quality, customer satisfaction and service \\
quality and customer satisfaction. \\
b. Dependent Variable: Customer loyalty.
\end{tabular}

Hypothesis 1: Service quality will not have a significant positive relationship with customer loyalty in the hospitality industry in Cape Coast, Ghana.

The findings show a positive relationship between the independent variable (service quality) and the dependent variable (customer loyalty) with beta value of .524 . The .524 beta value which is equal to $(52.4 \%)$ depicts an increase in customer loyalty which is influenced by service quality. The relationship between the two variables is said to be significantly positive therefore, the null hypothesis of the study H0: service quality will not have a positive relationship with customer loyalty in the hospitality industry in Cape Coast, Ghana, was rejected whist we conclude that a significant positive relationship exists between service quality and customer loyalty in the hospitality industry in Cape Coast, Ghana. The result of the study is consistent with the work of Liat et al. [68] who found out that service quality has a significant and positive direct relationship with customer loyalty. It also in consonance with the study of Allan [69] who found out that service quality positively affects loyalty. Table 9 presents the results.

Hypothesis 2: Customer satisfaction will not have a significant positive relationship with customer loyalty in the hospitality industry in Cape Coast, Ghana.

The results obtained from the statistics demonstrate a significant positive relationship between Customer satisfaction (independent variable) and customer loyalty (dependent variable). The findings revealed a beta value of .475 implying that $(47.5 \%)$ increases in customer loyalty is as a result of customer satisfaction. Therefore, the null hypothesis of the study H0: customer satisfaction will not have a significant positive relationship with customer loyalty in the hospitality industry in Cape Coast, Ghana, was 
rejected whilst we conclude that there is a significant positive relationship between customer satisfaction and customer loyalty in the hospitality industry in Cape Coast, Ghana. The findings of the study support the work of Liu et al. [70] whose study revealed a strong correlation between customer satisfaction and customer loyalty. The result is presented in table 9 .

Hypothesis 3: Service quality and customer satisfaction will not have a significant positive relationship with customer loyalty in the hospitality industry in Cape Coast, Ghana.

The results obtained from the regression analysis showed significant positive relationship between service quality and customer satisfaction and customer loyalty in the hospitality industry in Cape Coast, Ghana. This is evident in the beta value of .689 . The .689 beta value $(68.9 \%)$ implies an increase in customer loyalty which occurred is as a result of both service quality and customer satisfaction. Therefore, the null hypothesis of the study H0: service quality and customer satisfaction will not have a significant positive relationship with customer loyalty in the hospitality industry in Cape Coast, Ghana, was rejected whist we conclude that both service quality and customer satisfaction have a significant positive relationship with customer loyalty in the hospitality industry in Cape Coast, Ghana. The findings of the study corroborate the study of Joudeh \& Dandis [71] in Amman, Jordan. Table 9 presents the results.

TABLE 9: COEFFICIENTS

\begin{tabular}{cccccc}
\hline Model & $\begin{array}{c}\text { Unsolicited } \\
\text { B }\end{array}$ & $\begin{array}{c}\text { Coefficients } \\
\text { Std. Error }\end{array}$ & $\begin{array}{c}\text { Standardized } \\
\text { Coefficients } \\
\text { Beta }\end{array}$ & T & Sig. \\
\hline Constant & .482 & .412 & & .686 & .525 \\
$\begin{array}{c}\text { Service } \\
\text { Quality }\end{array}$ & .634 & .382 & .524 & 22.14 & .001 \\
$\begin{array}{c}\text { Customer } \\
\text { Satisfaction } \\
\text { Service }\end{array}$ & .422 & .462 & .475 & 24.20 & .025 \\
$\begin{array}{c}\text { Quality \& } \\
\text { Customer }\end{array}$ & .812 & .344 & .689 & 24.12 & .000 \\
Satisfaction & & & & & \\
\hline Dependent Variable: Customer loyalty & & & & &
\end{tabular}

\section{CONCLUSION AND RECOMMENDATIONS}

\section{A. Conclusion}

The findings of the study revealed that the hospitality industry in Cape Coast, Ghana, has a little more female customer than the male customers.

The study showed that the age groups 40-49 (37.5\%) and $50-59(31.2 \%)$ were the slightly majority in the hospitality industry in Cape Coast, Ghana. Followed by age group 30$39(21.3 \%)$ and age group 20-29 (10\%) respectively.

Customers with other certificates 140 (43.8\%) were the slightly majority in the hospitality industry in Cape Coast, Ghana, followed by master's degree holders 80 (25.0\%) and bachelor's degree holders 66 (20.6\%). Professional certificate holders were the least $34(10.6 \%)$ customers. It is apparent that customers in the hospitality industry in Cape Coast, Ghana, have attained varied level of education.

The statistics showed a significant positive relationship between service quality and customers' loyalty in the hospitality industry in Cape Coast, Ghana. This is demonstrated by the beta value of $(52.4 \%)$. By implication, the given beta value implies that service quality has a significant of $52.4 \%$ influence on customers' loyalty in the hospitality industry in Cape Coast, Ghana, whist the remaining which is equal to $47.6 \%$ are influenced by other variables.

The findings revealed a significant positive relationship between customer satisfaction and customers' loyalty in the hospitality industry in Cape Coast, Ghana. The beta value of (47.5\%) demonstrates this relationship. By implication, the given beta value shows that customer satisfaction has a significant $47.5 \%$ influence on customers' loyalty in the hospitality industry in Cape Coast, Ghana, whist the remaining which is equal to $52.5 \%$ are influenced by other variables.

The results showed that both service quality and customer satisfaction have a significant positive relationship with customers' loyalty in the hospitality industry in Cape Coast, Ghana, with a given beta value of $(68.9 \%)$. The given beta value implies that both service quality and customer satisfaction have a significant of $68.9 \%$ influence on customers' loyalty in the hospitality industry in Cape Coast, Ghana, whist the remaining which is equal to $31.1 \%$ are influenced by other variables.

\section{B. Recommendation}

It was recommended that the firms in the hospitality industry in Cape Coast, Ghana, should strive to continue the delivery of quality service to ensure customers' loyalty. This can be done by maintaining consistent quality service performance.

The study recommended that the firms in the hospitality industry in Cape Coast, Ghana, should continue to endeavour to meet customers' expectation since it engenders loyalty. Periodic market research is imperative to help identify emerging needs of customers so as to enhance the loyalty.

Furthermore, it was recommended that both service quality and customer satisfaction must not be toyed with in the hospitality industry in Cape Coast, Ghana, given that the customer has become sophisticated with continuous evolving needs.

\section{Future Studies}

This study investigated service quality and customer satisfaction in the hospitality industry in Cape Coast, Ghana. Future studies could be carried out with a focus on a single sector such as hotel or restaurant in the hospitality industry. With Ghana boasting of avalanche tourist attraction sites in various parts of the country, the study could also be replicated in a different region with a larger sample-size.

\section{REFERENCES}

[1] Wilson, J. P., \& Campbell, L. (2020). ISO 9001: 2015: the evolution and convergence of quality management and knowledge managemen for competitive advantage. Total Quality Management \& Business Excellence, 31(7-8), 761-776.

[2] Ryall, J., \& Kruithof, J. (2001). The Quality Systems Handbook. Consensus Books.

[3] Zeithaml, V. A., Parasuraman, A., \& Malhotra, A. (2000). A conceptual framework for understanding e-service quality: implications for future research and managerial practice (No. 115) Cambridge, MA: Marketing Science Institute. 
[4] Hoffman, K. D., \& Bateson, J. E. (2001). Essentials of services marketing: Concepts, strategies and cases. South-Western Pub.

[5] Seth, N., Deshmukh, S. G., \& Vrat, P. (2005). Service quality models: a review. International journal of quality \& reliability management.

[6] Gustafsson, A., Nilsson, L., \& Johnson, M. D. (2003). The role of quality practices in service organizations. International Journal of Service Industry Management.

[7] Khan, M. M., \& Fasih, M. (2014). Impact of service quality on customer satisfaction and customer loyalty: Evidence from banking sector. Pakistan Journal of Commerce and Social Sciences (PJCSS), 8(2), 331-354.

[8] Sureshchandar, G. S., Rajendran, C., \& Anantharaman, R. N. (2002). The relationship between service quality and customer satisfactiona factor specific approach. Journal of services marketing.

[9] Hansemark, O. C., \& Albinsson, M. (2004). Customer satisfaction and retention: the experiences of individual employees. Managing Service Quality: An International Journal.

[10] Kotler, P. (2009). Marketing management: A south Asian perspective. Pearson Education India.

[11] Liu, V., \& Khalifa, M. (2003). Determinants of satisfaction at different adoption stages of Internet-based services. Journal of the association for information systems, 4(1), 12.

[12] Brophy, C., Blackler, A., \& Popovic, V. (2015, November). Aging and everyday technology. In Proceedings of the 6th IASDR (The International Association of Societies of Design Research Congress) (pp. 250-265). IASDR (The International Association of Societies of Design Research).

[13] Hennayake, H. M. G. Y. (2017). Impact of service quality on customer satisfaction of public sector commercial banks: A study on rural economic context. International Journal of Scientific and Research Publications, 7(2), 156-161.

[14] Chen, C. W. (2010). Impact of quality antecedents on taxpayer satisfaction with online tax-filing systems-An empirical study. Information \& Management, 47(5-6), 308-315.

[15] Johansson, J., \& Ström, F. (2002). Customer relationship management: case studies of five Swedish companies.

[16] Zairi, M. (2000). Managing customer satisfaction: a best practice perspective. The TQM magazine.

[17] Hussain, R., Al Nasser, A., \& Hussain, Y. K. (2015). Service quality and customer satisfaction of a UAE-based airline: An empirical investigation. Journal of Air Transport Management, 42, 167-175.

[18] Goodman, J. (2019). Strategic customer service: Managing the customer experience to increase positive word of mouth, build loyalty, and maximize profits. Amacom.

[19] Newman, K. (2001). Interrogating SERVQUAL: a critical assessment of service quality measurement in a high street retail bank International journal of bank marketing.

[20] Caruana, A. (2002). Service loyalty. European journal of marketing.

[21] Saleem, H., \& Raja, N. S. (2014). The impact of service quality on customer satisfaction, customer loyalty and brand image: Evidence from hotel industry of Pakistan. Middle-East Journal of Scientific Research, 19(5), 706-711.

[22] Prabhakaran, S., \& Satya, A. S. (2003). An insight into service attributes in banking sector. Journal of Services Research, 3(1), 157.

[23] Brady, M. K., \& Cronin Jr, J. J. (2001). Some new thoughts on conceptualizing perceived service quality: a hierarchical approach. Journal of marketing, 65(3), 34-49.

[24] Amoako, G. K., Neequaye, E. K., Kutu-Adu, S. G., Caesar, L. D., \& Ofori, K. S. (2019). Relationship marketing and customer satisfaction in the Ghanaian hospitality industry. Journal of Hospitality and Tourism Insights.

[25] Opuni, F. F., Opoku, E., \& Oseku-Afful, M. (2014). The effect of relationship marketing on service quality and customer satisfaction in the hospitality sector in Ghana: The moderating role of service providers' emotional intelligence. British Journal of Marketing Studies, 2(6), 1-16.

[26] Poku, K., Zakari, M., \& Soali, A. (2013). Impact of service quality on customer loyalty in the hotel industry: An empirical study from Ghana. International Review of Management and Business Research, 2(2), 600-609.

[27] Wisniewski, M. (2001). Using SERVQUAL to assess custome satisfaction with public sector services. Managing Service Quality: An International Journal.

[28] Parasuraman, A., Zeithaml, V. A., \& Berry, L. L. (1988). Servqual: A multiple-item scale for measuring consumer perc. Journal of retailing, 64(1), 12.

[29] Nitecki, D. A., \& Hernon, P. (2000). Measuring service quality at Yale University's libraries. The Journal of Academic Librarianship, 26(4), 259-273.
[30] Lewis, B. R., \& Mitchell, V. W. (1990). Defining and measuring the quality of customer service. Marketing intelligence \& planning.

[31] Arnauld, E. J., Price, L.L., Zinkhan, G. M. (2002), Consumers, New York, NY: Mc-Graw-Hill Higher Education.

[32] Parasuraman, A., Zeithaml, V. A., \& Berry, L. L. (1985). A conceptual model of service quality and its implications for future research. Journal of marketing, 49(4), 41-50.

[33] Hill, N., Roche, G., \& Allen, R. (2007). Customer satisfaction: the customer experience through the customer's eyes. The Leadership Factor.

[34] Ofosu-Boateng, I., \& Agyei, S. D. (2020). Effect of Custome Satisfaction and Marketing Communication Mix on Customers' Loyalty in the Ghanaian Banking Industry. European Journal of Management and Marketing Studies, 5(4).

[35] Kaura, V., Datta, S. K., \& Vyas, V. (2012). Impact of Service Quality on Satisfaction and Loyalty: Case of Two Public Sector Banks. Vilakshan: The XIMB Journal of Management, 9(2).

[36] Homburg, C., \& Giering, A. (2001). Personal characteristics as moderators of the relationship between customer satisfaction and loyalty - an empirical analysis. Psychology \& Marketing, 18(1), 43 66.

[37] McColl-Kennedy, J., \& Schneider, U. (2000). Measuring customer satisfaction: why, what and how. Total quality management, 11(7), 883-896.

[38] Naylor, M., \& Greco, S. (2002). Customer Chemistry: How to Keep the Customers You Want and Say" good-bye" to the Ones You Don't. McGraw Hill Professional.

[39] Kim, M. K., Park, M. C., \& Jeong, D. H. (2004). The effects of customer satisfaction and switching barrier on customer loyalty in Korean mobile telecommunication services. Telecommunications policy, 28(2), 145-159.

[40] Gerpott, T. J., Rams, W., \& Schindler, A. (2001). Customer retention, loyalty, and satisfaction in the German mobile cellula telecommunications market. Telecommunications policy, 25(4), 249 269

[41] Bansal, S., \& Gupta, G. (2001). Building Customer Loyalty Businessto-Business Conimerce. Customer relationship management: Emerging Concepts, Tools, and Applications, 273.

[42] Kumar, M., Kee, F. T., \& Manshor, A. T. (2009). Determining the relative importance of critical factors in delivering service quality of banks. Managing Service Quality: An International Journal.

[43] Wong, A., \& Sohal, A. (2003). Service Quality and Customer loyalty perspectives on two levels of retail relationships. Journal of service marketing

[44] Aydin, S., \& Özer, G. (2005). The analysis of antecedents of customer loyalty in the Turkish mobile telecommunication market. European Journal of marketing.

[45] Wong, A., \& Sohal, A. (2003). Service quality and customer loyalty perspectives on two levels of retail relationships. Journal of services marketing.

[46] Ciavolino, E., \& Dahlgaard, J. J. (2007). ECSI-customer satisfaction modelling and analysis: a case study. Total Quality Management, $18(5), 545-554$.

[47] Namkung, Y., \& Jang, S. S. (2008). Are highly satisfied restaurant customers really different? A uality perception perspective. International Journal of Contemporary Hospitality Management

[48] Shafei, I., \& Tabaa, H. (2016). Factors affecting customer loyalty for mobile telecommunication industry. EuroMed Journal of Business, 11(3), 347

[49] Kwak, D. H., McDaniel, S., \& Kim, K. T. (2012). Revisiting the satisfaction-loyalty relationship in the sport video gaming context: The mediating role of consumer expertise. Journal of Sport Management, 26(1), 81-91.

[50] Bowen, J. T., \& Chen, S. L. (2001). The relationship between customer loyalty and customer satisfaction. International journal of contemporary hospitality management.

[51] Chingang Nde, D., \& Lukong, P. (2010). Using the SERVQUAL Model to assess Service Quality and Customer Satisfaction.: An Empirical Study of Grocery Stores in Umeå.

[52] McDougall, G. H., \& Levesque, T. (2000). Customer satisfaction with services: putting perceived value into the equation. Journal of services marketing.

[53] Negi, R. (2009). User's perceived service quality of mobile communications: experience from Ethiopia. International Journal of Quality \& Reliability Management

[54] Mahamad, O., \& Ramayah, T. (2010). Service quality, custome satisfaction and loyalty: A test of mediation. International business research, 3(4), 72 .

[55] Gray, B., \& Boshoff, C. (2004). The relationships between service quality, customer satisfaction and buying intentions in the private 
hospital industry. South African journal of business management, 35(4), 27-37.

[56] Naderian, A., \& Baharun, R. (2015). Service Quality and Consumer Satisfaction and Loyalty association Moderated by Switching Cost in Hospitality Industry. International Journal of Hospitality \& Tourism Systems, 8(1).

[57] Pereira, D., Giantari, N. G. K., \& Sukaatmadja, I. P. G. (2016) Pengaruh Service Quality terhadap Satisfaction dan Customer Loyalty Koperasi Dadirah di Dili Timor-Leste. E-Jurnal Ekonomi dan Bisnis Universitas Udayana, 5(3), 455-488.

[58] Baker, D. A. \& J. L. Crompton (2000), "Quality, satisfaction and behavioral variables," Annals of Tourism Research, 27 (3), 785-804.

[59] Owens, L. K. (2002). Introduction to survey research design. In SRL fall 2002 seminar series (pp. 78-105).

[60] Opoku, K. (2005). Benefits sharing and participatory resource management. Reconciling policy reforms with forest legislation, 1826.

[61] Castilo, Joan J. (2009). Research population. http:www.experimentresources.com/research population. copyright.

[62] Panneeerselvam, R. (2009). Research Methodology, New Delhi: International Journal of Management and Systems, Vol (7), pp. 1639.

[63] Stangor, C. (2007). External Validity. Research methods for the behavioural sciences, pp.238-253.

[64] Saunders, M., Lewis, P., \& Thornhill, A. (2009). Research methods for business students. Pearson education.

[65] Morse, J. M., Barrett, M., Mayan, M., Olson, K., \& Spiers, J. (2002). Verification strategies for establishing reliability and validity in qualitative research. International journal of qualitative methods, 1(2), 13-22.

[66] Kök, A. G., \& Fisher, M. L. (2007). Demand estimation and assortment optimization under substitution: Methodology and application. Operations Research, 55(6), 1001-1021.

[67] Sekaran, U. (2000). Measurement: Scaling, reliability, validity Research Methods for Business (Vol. 3, pp. 196-218).

[68] Liat, C. B., Mansori, S., \& Huei, C. T. (2014). The associations between service quality, corporate image, customer satisfaction, and loyalty: Evidence from the Malaysian hotel industry. Journal of hospitality marketing \& management, 23(3), 314-326.

[69] Allan, M. M. (2016). The Relationship Between Service Quality and Customer Satisfaction and Retention in Ghana's Luxury Hotels. IUP Journal of Marketing Management, 15(4).

[70] Liu, H., Chen, Y., Zha, Y., Ling, L., \& Wang, D. (2018). The effect of satisfaction on loyalty in consumption and service industry based on meta-analysis and it's algorithm. Wireless Personal Communications, 103(1), 963-982.

[71] Joudeh, J. M., \& Dandis, A. (2018). Service Quality, Customer Satisfaction and Loyalty in an Internet Service Providers. International Journal of Business and Management, 13(8), 108-120. 